\title{
Transition into Teaching: Second Career Teachers' Professional Identity
}

\author{
Gabriella Shwartz ${ }^{1 *}$, Yehudit Judy Dori ${ }^{1,2}$ \\ ${ }^{1}$ Faculty of Education in Science and Technology, Technion, Israel Institute of Technology, Haifa, ISRAEL \\ ${ }^{2}$ Samuel Neaman Institute for National Policy Research, Haifa, ISRAEL
}

Received 26 June 2020 • Accepted 26 August 2020

\begin{abstract}
Using the identity lens as a theoretical framework, we studied 42 novice second career chemistry teachers, who had previously worked as chemists and participated in an alternative certification program (ACP) at a science and engineering research university. Our goal was to understand the transition process of these teachers into the teaching profession as they shape their identity and navigate through the contexts of the preparation program and the school system.

Results showed that the career changers attributed their identity development to a variety of program identity resources, which shape one's identity: coursework, field experiences, and social contexts. We saw that the transition to the teaching profession was mainly due to their desire to contribute to society.

Investigating three case studies, we learned that through the active participation, one's vision of the particular kind of teacher one aspires to be has developed within the unique learning environment created in the program.
\end{abstract}

Keywords: second career teachers, teacher's professional identity, career changers, chemistry education

\section{INTRODUCTION}

The ongoing decrease in the number of professionals who practice science, technology, engineering and mathematics - STEM, as well as teachers in these disciplines has created a crisis that hinders sustainable economic development worldwide (Diekman, \& Benson-Greenwald, 2018; Treagust, Won, Petersen, \& Wynne, 2015; Wang and Degol, 2013). Effective chemistry teachers motivate students to major in chemistry and pursue it as a career (Avargil, Kohen, \& Dori, 2020; Salta, Gekos, Petsimeri, and Koulougliotis, 2012). The chemical industry is an essential part of Israel's economy ${ }^{1}$. Teachers play a key role in preparing a new generation of chemists, chemical engineers, and other professionals in related fields.

To enhance the integration of high-quality teachers into the educational system in Israel, alternative certification programs (ACPs) for second career STEM teachers have been established (Hazzan, HeydMetzuyanim, Even-Zahav, Tal, \& Dori, 2018). We define second career chemistry teachers as career changers, who have a bachelor's degree in chemistry or chemistryrelated field, worked at least five years in industry, and left their jobs either partially, or completely to pursue a chemistry education degree (Etherington, 2009).

We explore chemistry teachers who participated in an ACP for second career teachers. The program was conducted at a department of education in a research university - Technion, Israel Institute of Technology. Graduates of this institution who hold STEM degrees are eligible to participate in the ACP program free of charge and earn an additional bachelor's degree, or extend their degree to include a Teaching Certificate (Hazzan et al., 2018). This program differs from traditional teacher education programs in several aspects, including the

${ }^{1}$ In Israel, $40 \%$ of the industrial export, 30\% of the industrial revenue, and $9 \%$ of the industrial employment is dependent on its chemical industry. http://www.economy.gov.il/Industry/Industry_and_Environment/Chemical_Industry/Pages/Chemical_Industry.aspx\#GovXParagraphTitle 3

(C) 2020 by the authors; licensee Modestum. This article is an open access article distributed under the terms and conditions of the Creative Commons Attribution License (http://creativecommons.org/licenses/by/4.0/).

$\checkmark$ gabbysh@technion.ac.il (*Correspondence) $\square$ yjdori@technion.ac.il 


\section{Contribution to the literature}

- At the theoretical level, we used identity lens for understanding second career chemistry teachers transition process in a critical point of their career pathway- from a preparation program into the school system.

- Practically, we identified the practices that support the preparation of career changers and their needs.

- With respect to career transition from industry to teaching, this study provides a roadmap for educators, principals and mentors for developing the vision and skills required to help second career teachers become the professionals they aspire to be.

target student population, the admission requirements, the scholarships provided, the duration, and the pedagogical tools students are provided with (DarlingHammond, 2017).

In this research, we aim to understand the role of an $\mathrm{ACP}$ in the transition of career changers into the teaching profession.

Research on second career teachers is limited (Tigchelaar, Brouwer, and Vermunt 2010; Baeten, and Meeus, 2016). Previous research focused on second career teachers' aspiration to teach, with little attention to the experiences of these teachers-to-be during their $\mathrm{ACP}$ and later, as they become teachers (Richardson and Watt, 2006; Williams, 2010).

The present research fills a gap in the literature by addressing in depth second career teachers' experiences in two learning spaces and two sequential, crucial stages in the teaching profession: their preparation program followed by their beginning as novice teachers in the school system. Our research question was: Which of the identity resources implemented in the program, chemistry teachers perceived as supportive in: (a) shaping their professional identity as novice teachers, and (b) providing them with tools to integrate their knowledge and skills into teaching chemistry?

Our study offers insights into the effective elements of an ACP for prospective second career chemistry teachers. We also suggest using identity resources implemented in the program for comparing the efficacy of different practices in shaping one's identity. Based on the findings, we recommend how administrators, primarily principals and mentors, can help alleviate difficulties that arise during the transition of career changers to the teaching profession while nurturing their identity as professionals.

\section{CONCEPTUAL FRAMEWORK}

The transition from an industrial chemistry career into the teaching profession encompasses an entirely new path of becoming a different kind of professional a chemistry teacher.

\section{Teachers' Professional Identity}

In this research, we adopt the identity lens to understand the process of becoming a career changer in two institutional contexts: teachers' preparation program and the school system (Beltman et al., 2015). Each such context includes a set of identity resources such as practices, norms and professional standards that nurture the development of teacher identity while aiming to ensure successful integration of novice teachers into the teaching profession (Richmond, Juzwik, \& Steele, 2011; Gracia, Rodríguez, \& Pedrajas, 2019 ).

Though a number of scholars investigated teacher's identity development (Beltman, Glass, Dinham, Chalk, \& Nguyen, 2015; Luehmann, 2016; van der Wal, Oolbekkink-Marchand, Schaap, \& Meijer, 2019), we aim to understand how the construct of identity develops and shapes among teachers who already had previous career identities and characterize their perceptions of their own future in two sequential stages of careerpreparation program and practicing as novice teachers.

Researchers of teacher education claim that knowledge of the self is a crucial element in the way teachers construct the nature of their work (Gracia et al., 2019; Luehmann, 2016; Williams, 2010). Findings confirm that (a) events and experiences in the personal lives of teachers are directly linked to the performance of their professional roles (Olsen, 2016; Volkmann and Anderson, 1998; Richmond, 2016), and (b) professional identity is not a stable product, but rather an ongoing, continually changing, active process (Pillen et al., 2013; van der Wal et al., 2019). For example, to capture the dynamic nature of identity development, McCaslin (2009) proposed a model consisting of personal, cultural and social aspects. Beijaard and colleagues (2004) explained professional identity as something established and maintained through the interaction in social situations and negotiation of roles within the particular context.

In an effort to identify central components that constitute professional identity of pre-service teachers, Lasky (2005) presented several factors, such as commitment, knowledge, beliefs, values, emotional well-being, and vulnerability. Avalos and De Los Rios (2013) argued that aspects of motivation and commitment, work requirements, satisfaction and, selfefficacy, are essential in how teachers identify themselves as professionals. Moreover, individuals' beliefs and personal experiences, as well as their 
perceptions of what is expected in a particular context, are an important aspect of teacher identity, and they influence teachers' choice of certain teaching practices (Horn, Nolen, Ward \& Campbell, 2008; Katz et al., 2011; Leshem, 2019).

In line with these characteristics, we decided to conceptualize professional identity of teachers with respect to two main perspectives: (1) professional identity as a process of reconciling the personal and professional side of becoming a teacher (Olsen, 2016; Volkmann and Anderson, 1998; Trent, 2018), and (2) professional identity as influenced not only by teachers' personal characteristics, but also by professional contexts, such as their education program, colleagues, teachers' knowledge, skills, prior experiences, and educational attitudes (Gee, 2000; Olsen, 2016). Due to the nature of our participants, who are second career teachers, their professional identity development as teachers add extra dynamics: they have early beliefs about the teaching profession which are influenced by their previous career and strengthen even more as they enter their classroom (Williams, 2010; Leshem, 2019).

\section{Reviewing the Transition to Teaching as a Career Changer}

Prior career experience impacts the ways second career teachers experience teacher education. The connections between previous experience and teaching practice is vital to the construction of their new professional identity (Williams, 2010). Career changers undergo personal and professional transformations as they transition to the teaching profession (Tigchelaar et al., 2014). Snyder and colleagues (2013) examined the transition of STEM career changers into teaching, and emphasized the importance of viewing this transition as a "social rebirth," since second career teachers must make adjustments to the change in their salary and social status (Johnson, 2015). Several studies indicate that second career teachers' earlier experiences influence on how they cope with the conditions in their new professional context. Eifler and Potthoff (1998), who reviewed 40 studies dealing with second career teachers, showed that they can draw on earlier experiences that taught them how to adapt to new situations. A variety of difficulties were documented in the literature, including transitioning from being an expert in one field to a novice teacher status, dissatisfaction with their new salary and responsibilities, frustration regarding inefficiencies of school bureaucracies, and being a novice at a point in life when one may already have had a successful career (Powers, 2002; Wilkin, 2017).

Finding ways to fill the gap between first-career experiences and new experiences as second career teachers can positively impact the learning process of second career teachers and help establish new beliefs of teaching and learning (Tigchelaar et al., 2010; Tsybulsky \& Muchnik-Rozanov, 2019). Teacher education programs can modify perceptions and beliefs of what it means to be a teacher, but the change in their role from being a student to being a teacher is longitudinal process that requires the guidance of mentors and colleagues (Buldur, 2017; Williams, 2010). Another important prior career aspect is knowledge and successes in previous jobs (Troesch, and Bauer, 2017). Koeppen and Griffith (2003) found that second career teachers are often restrained about the need to learn more in order to become effective teachers, as they believe their extensive content knowledge is sufficient.

The perception that all second career teachers come with rich discipline-specific content knowledge is not always accurate. Lee and Lamport (2011) found that having previous work experience within the science domain that a second career teacher intends to teach does not automatically mean one will be a good fit for teaching (Antink-Meyer, \& Brown, 2017). In the study of Fry and Anderson (2011), career changers encountered challenges while trying to explain complex concepts to struggling students, even though they were subject matter experts.

\section{RESEARCH SETTING}

In response to the acute shortage in STEM teachers in Israel, our university launched Views - an educational initiative that invites our graduates to earn an additional bachelor's degree in science or engineering education. The Views program differs from traditional teacher education programs in Israel in (a) the student population - with at least B.Sc. in STEM, (b) the program duration - four semesters instead of eight, (c) the program characteristics - focusing mainly on learning the pedagogical content knowledge, assessment knowledge and practices, and (d) the tuition, which is free for Views students.

Many of the participants come from prestigious careers in industry, civil service, and research institutes (Hazzan and Ragonis, 2014). Our teacher preparation program includes identity resources of coursework, field experiences, and social contexts that encourages experiencing personal, professional, and emotional challenges. This unique context provides us with evidence that enables analysis of the transition process to teaching through teacher's identity development.

\section{The ACP Chemistry Education Track - The Views Program}

The chemistry education track aims to prepare active, skilled, and enthusiastic research-oriented chemistry teachers who are involved in conducting practical research in science and chemistry education (e.g. action research), and are capable of lifelong learning. Our goal in the program has been to strengthen second career chemistry teachers' mastery of key concepts and pedagogical instruction skills in chemistry while 


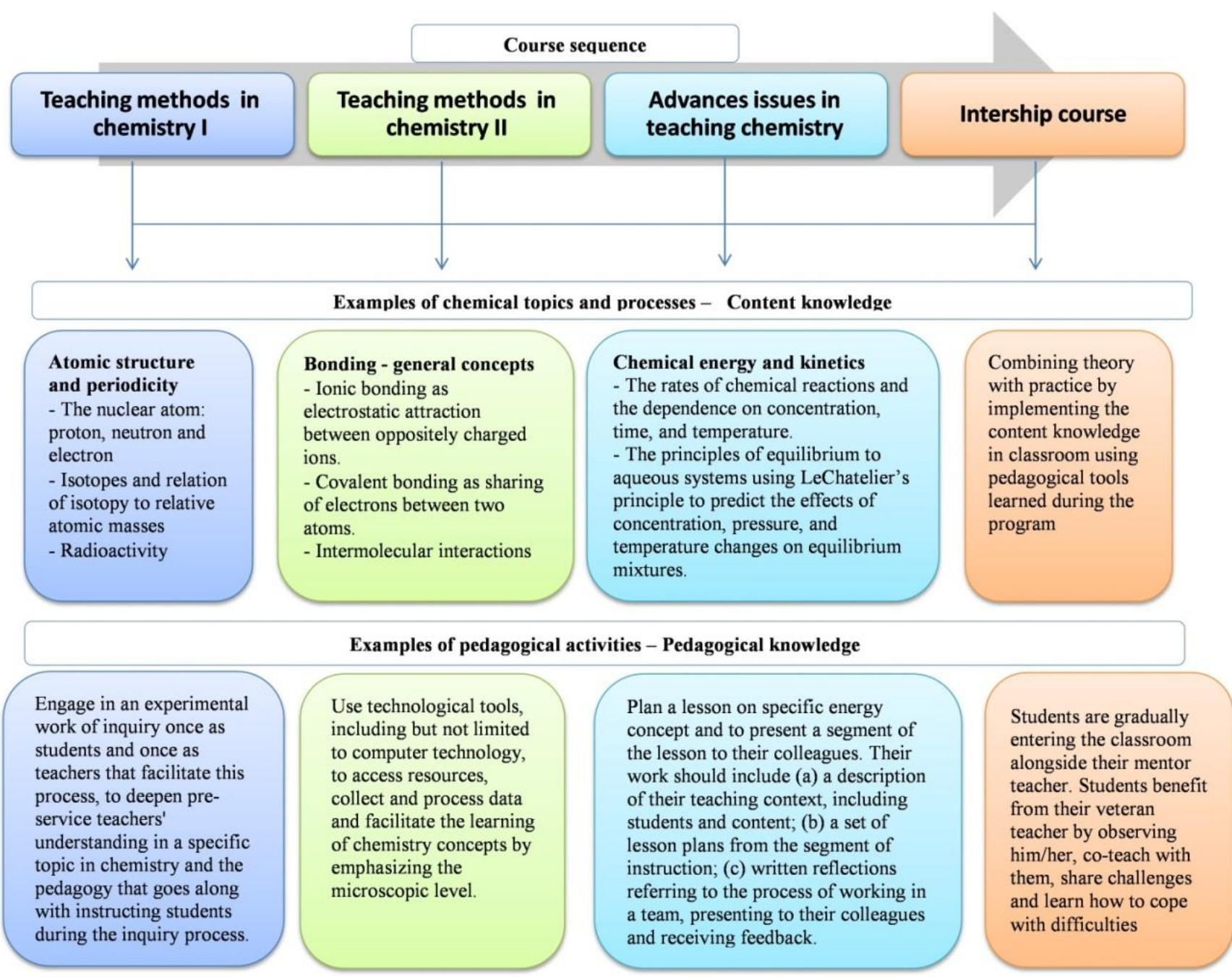

Figure 1. Course sequence, chemical concepts taught, and examples of pedagogical activities implemented in the courses

addressing their personal characteristics of beliefs with respect to what it means to be a teacher. Figure 1 shows an overview of the main topics and chemical concepts taught in some of the courses and examples of pedagogical activities implemented in the courses (Hazzan et al., 2018).

According to Slavich and Zimbardo (2012), changes in beliefs and the formation of a professional identity are most likely to occur in social contexts. Therefore, students are exposed to collaborative learning. Social interactions expose individuals to viewpoints that differ from their own and provide the opportunity to support others who have similarly idealistic goals about improving STEM education. Indeed, engaging the preservice chemistry teachers in collaborative, interdependent problem solving and discussions is critical for promoting positive learning-related values of and beliefs about the teaching profession.

\section{RESEARCH METHODOLOGY}

Qualitative research is useful for elucidating the relationships between social processes and the meanings that participants attribute to social situations (Marshall \& Rossman, 2014). We applied a descriptive case study approach to understand the role of the Views program in preparing career changers for their anticipated shift into the school environment while developing their professional identity (Creswell, 2002; Stake, 2013). Combining data from semi-structured interviews, openand close-ended questionnaires, and an analysis of teachers' designed assignments, enabled the triangulation of the findings, which, in turn, increased the validity of the findings, reduced the subjectivity of our interpretations, and enhanced the trustworthiness of the conclusions (Jonsen, and Jehn, 2009).

\section{RESEARCH PARTICIPANTS}

We define second career chemistry teachers as teachers with a bachelor's degree in chemistry or a related field, worked at least five years in industry and left their jobs either partially or completely to pursue a chemistry education degree (Etherington, 2009). We used criterion-based sampling or purposive sampling, to select the participants who fit a given set of criteria. This 


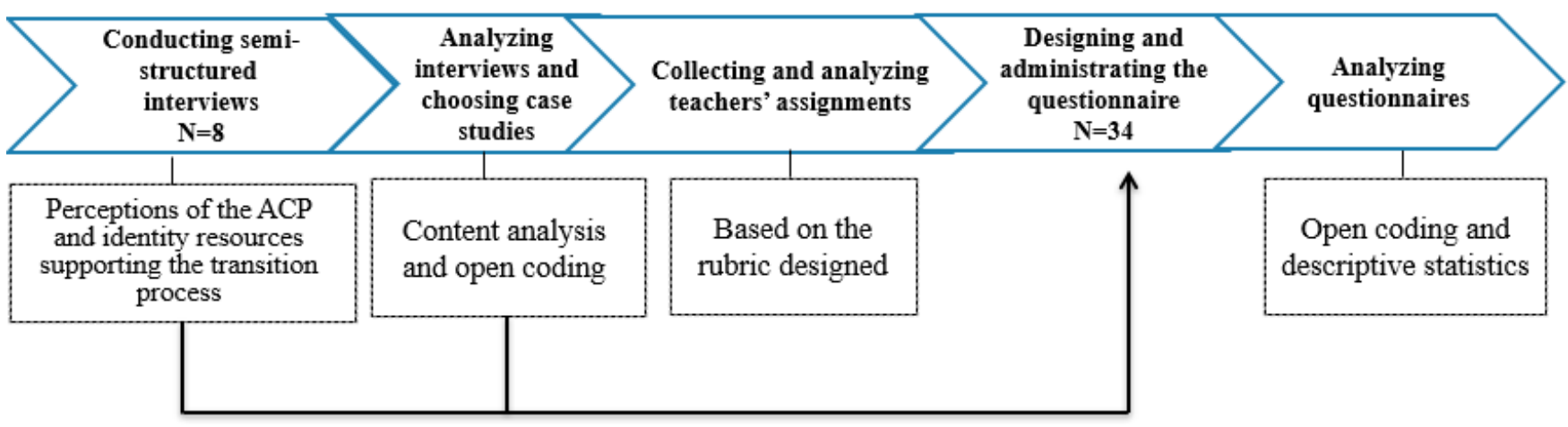

Figure 2. Research method and tools

sampling allowed us to refer to the key research points while also providing for diversity within the sample (Ritchie \& Lewis, 2003). Our research population included 42 career changers who enrolled in the Views chemistry education track who studied over a period of two years, between 2015-2017. These teachers graduated the Views program and were novice teachers within their first, second or third year of teaching experience. Most of these pre-service teachers were females ( $88 \%)$. Their ages ranged from 25 to 39 , and most of them held B.Sc. degrees $(81 \%)$ in a variety of STEM disciplines, including chemistry, chemical engineering, and biotechnology and food engineering; Some held M.Sc. degrees (14\%).

\section{RESEARCH TOOLS AND DATA ANALYSIS}

An overview of research method and tools is presented in Figure 2.

As Figure 2 shows, data analysed from the interviews with eight novice chemistry teachers, who were Views graduates, served as the basis for choosing our case study teachers and later for designing the questionnaires. The questionnaires was administrated to additional 34 chemistry teachers served for triangulating the data from the interviews, applying our findings to an extended sample of participants, and presenting descriptive statistics of our findings.

\section{Interviews}

Semi-structured interviews were conducted with eight career changers who participated in the Views chemistry education path. The interviews were conducted during the students' last semester of the program while they were transitioning into the school system and already teaching $(\mathrm{N}=2)$ or after they had graduated from the program and started working as novice teachers $(\mathrm{N}=6)$. The goal of the interviews was to understand what second career chemistry teachers' perceived as identity resources in the ACP for supporting their: (a) identity shaping, and (b) transition into teaching. We asked teachers questions about the program (e.g., "What aspects of the Views program are worth preserving?") and its role in preparing graduates for their integration into the school system ("How did the Views program contribute to your transition into the teaching profession?"). Transcribed data was qualitatively analysed through content analysis (Fraenkel, Wallen, and Hyun, 2011) and open coding (Glaser and Strauss, 2017) to establish themes and main concepts. The analysis began with two researchers dividing the collected data into smaller statements that were later used to identify major themes (Creswell, Hanson, Clark Plano, \& Morales, 2007). Secondly, these segments were sorted to professional and personal aspects within the argument that professional identity is influenced by teachers' personal characteristics and by professional contexts, such as their colleagues, teachers' knowledge, skills, prior experiences, and educational attitudes.

Finally, to ensure a high degree of validity, three researchers reviewed the evidence. Working by consensus, they confirmed that the themes and categories corresponded with the research goals and narrative development.

\section{Case Studies of Three Second Career Chemistry Teachers}

We explored the experiences of career changers in two institutional contexts: the Views program and their classroom teaching following the Views program. To accomplish this, we used a multiple case study design (Stake, 2013), where the cases are similar, but each one is treated individually. We chose three of the eight second career teachers, Yasmin, Tiffany, and Phil2, and they served as three case studies. We chose to focus on these three teachers in order to provide an in-depth view of teachers with different first-career backgrounds. Phil had high-tech experience, Tiffany engaged in academic research, and Yasmin worked in the chemical industry. These teachers also represent various age groups and 
Table 1. Categories for evaluating teachers' designed assignments

\begin{tabular}{|c|c|}
\hline Category & High level assignment \\
\hline Thinking skills & Synthesis and evaluation \\
\hline $\begin{array}{l}\text { Chemistry level of understanding } \\
\text { (macro, micro, symbol and process) }\end{array}$ & Three levels of understanding are expressed \\
\hline Context based learning & Reference to everyday life situations in the macro and micro levels of the phenomena \\
\hline $\begin{array}{l}\text { Involves active learning and } \\
\text { engagement from the students }\end{array}$ & Active learning via implementing experiments and games \\
\hline Interdisciplinary & Incorporating another two disciplines besides chemistry \\
\hline Creativity & Including innovative elements besides questions, e.g., experiments or games \\
\hline Aligned with the curriculum & A full alignment between the assignments and the topics in high school chemistry curriculum \\
\hline Coherent and consistent & The development of the question difficulty is gradual, with a clear and logical sequence \\
\hline
\end{tabular}

sectors: Phil is 55 years old, while Yasmin and Tiffany are 30 and 35 years old, respectively.

We triangulated three data sources of these teachers' integration process into the teaching profession: interviews, questionnaires, and teachers' designed assignments. We transcribed the interviews and used them along with the teachers' designed assignments.

\section{Second Career Teachers' Designed Assignments}

To gain additional insights into how the identity resources in the Views program provided them with tools to integrate successfully their knowledge and practices into teaching chemistry and the way they implemented these resources into their practice, we asked our three case study teachers to administer to their classes assignments they had designed. These assignments, which were developed as part of the learning process at the Views program and their implementation reflect teaching in a real-life classroom setting, were analysed using a rubric we developed based on the research of Avargil, Herscovitz, and Dori (2012). Rubric categories included thinking skills, chemistry understanding level (macroscopic, microscopic, symbol, and process), context-based learning, interdisciplinarity, and creativity as presented in Table 1.

\section{Questionnaire}

Having analysed the interviews, we gained insights into the narrative of our case study teachers and what they perceived as important for a successful transition into the school environment. Based on this understanding, we designed the questionnaire using the categories presented in Table 1 . Since this study was part of a more extensive national-level research, which included additional populations such as first career teachers, Cronbach's alpha reliability estimates for all items was $\alpha=0.887$, and for each factor addressed in this study, the reliability was $a=0.883$, demonstrating a high level of internal consistency for all the factors. Then, the questionnaire was administered to an extended group of 34 second career chemistry teachers. Our two-part questionnaire began with demographic questions pertaining to participants' age, prior career, discipline of instruction, and years of experience in teaching. The second part addressed graduates' perceptions of the Views program, enabling them to express personal reflections. This part consisted of a closed-ended section, in which participants were asked to indicate the most important aspects and identity resources of the program that facilitated their transition into the school system and shaped their identity as professionals. Aspects that were the most supportive to their transition were coded as 3 , while aspects that were less significant for their integration into the school system were coded as 2 or 1 , and aspects that were not mentioned at all were coded as 0 . Frequency ' 0 ' of a specific aspect is not presented in the figures in the Results section, since this aspect was not sufficiently supportive or significant to their transition compared with other aspects. Although this ranking is one of several choices for ranking the top three choices, we can learn which aspects were less emphasized.

The data gleaned from the questionnaires were analysed via descriptive statistics of averages, frequency percentages, and standard deviations.

\section{RESULTS}

Our study explored identity resources that supported the teachers' career transition, as well as why and how these aspects were important for their transition. To elucidate both the role of the Views program in preparing career changers and their distinctive learning and teaching needs, we analysed our data by using identity as our theoretical lens. Working under the belief that professional identity is influenced both by the person and the context in which the teacher works, we divided the data into these two core aspects. When events or beliefs were found to be similar in nature, they were grouped together under a broader category. These categories were later clustered into identity resources, as presented in Table 2. 
Table 2. Themes and categories found during data analysis

\begin{tabular}{lll}
\hline Theme & Category & Identity resource \\
\hline Professional & Competencies & Content knowledge - CK \\
& Pedagogical content knowledge - PCK \\
& Technological knowledge - TK \\
& Teaching practice \\
& Transferring skills from first career \\
\cline { 2 - 3 } & Learning environment & Teamwork \\
& & Diverse learning environment \\
\cline { 2 - 3 } Personal & Beliefs & Enhancing personal ideals and understanding teachers' role
\end{tabular}

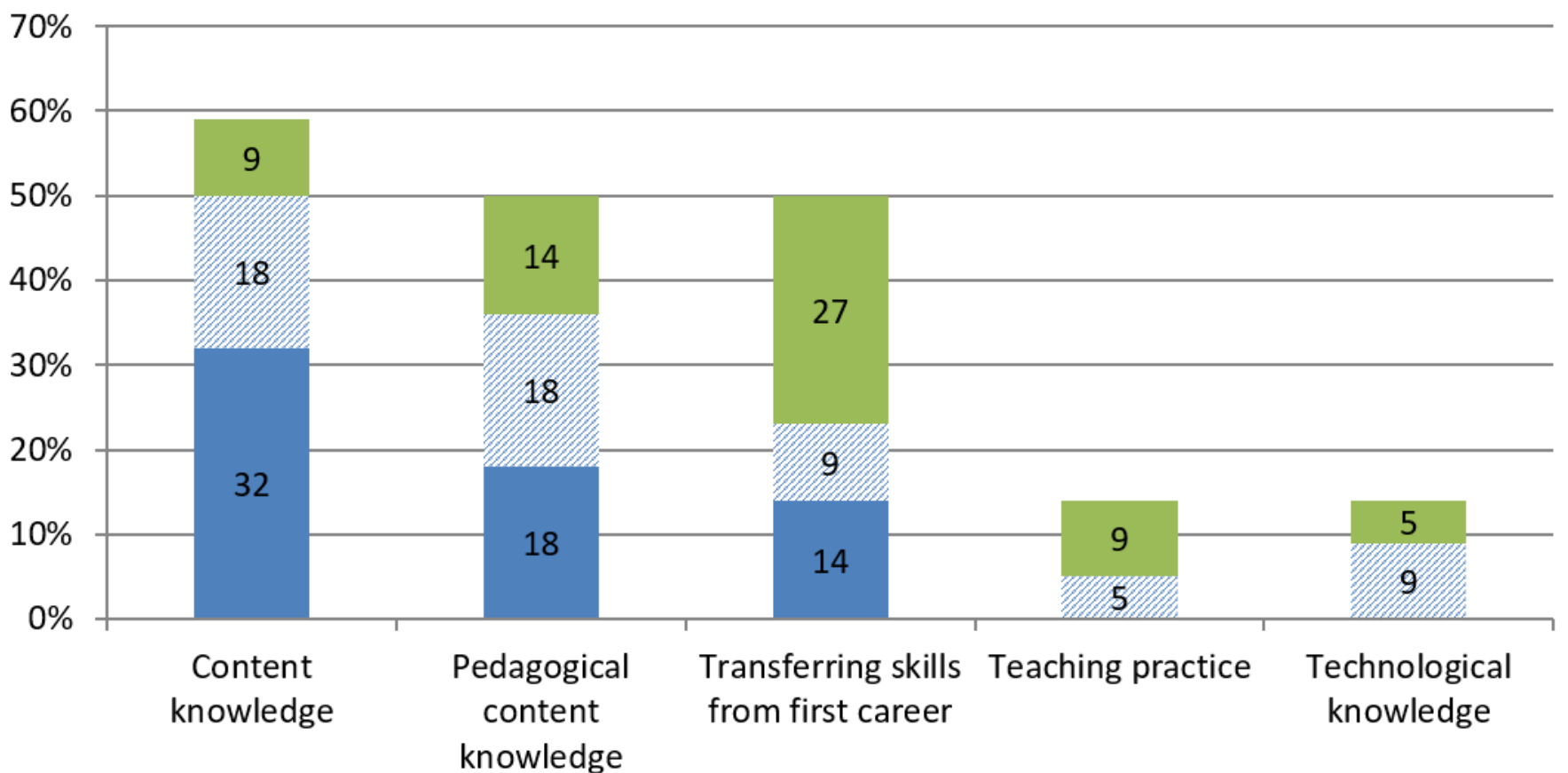

Amount of times teachers ranked ' 3 '

Amount of times teachers ranked ' 2 '

Amount of times teachers ranked ' 1 '

Figure 3a. Teachers' ranking of identity resources in the Views program - Competencies category

\section{ACP Identity Resources that Support Teachers' Transition}

Figure 3a presents teachers' ranking of several identity resources in the Views program according to their perceived level of nurturing their teacher's identity and preparedness for the teaching profession in the Competencies theme. Figure $3 b$ shows their ranking in the learning environment and personal beliefs category.

As Figure 3a shows, teachers felt that the chemistry content knowledge and the pedagogical content knowledge aspects of the program were: (a) meaningful in their process of shaping their identity as chemistry teachers, and (b) prepared them well to the teaching profession. Their identity was characterized by a strong foundation of pedagogical content knowledge. Additionally, participants felt that the program enabled them to apply their prior knowledge in their new career and to share these experiences with their peers and later in the classroom. We found that their first career experiences helped constructing new knowledge and qualities that shape their new professional identity as teachers. The two main competencies that the teachers felt they needed more exposure to and were lacking in the program were practice of teaching and acquisition of technological knowledge, neither of which was ranked at all by the teachers, scoring 0 . Teachers felt that the field experience they had received prior to finalizing their certification was insufficient, and they would appreciate more opportunities to implement the practical knowledge they had learned in a real classroom setting.

Examining Figure 3b, we see that the identity resource of creating a diverse learning environment and enhancing personal ideals were vital to and supportive of teachers' identity and integration. As teachers mentioned in the interviews, the unique learning environment in the Views program enabled first- and second career teachers to share ideas, learn practices from each other, and discuss the variety of teachers' 


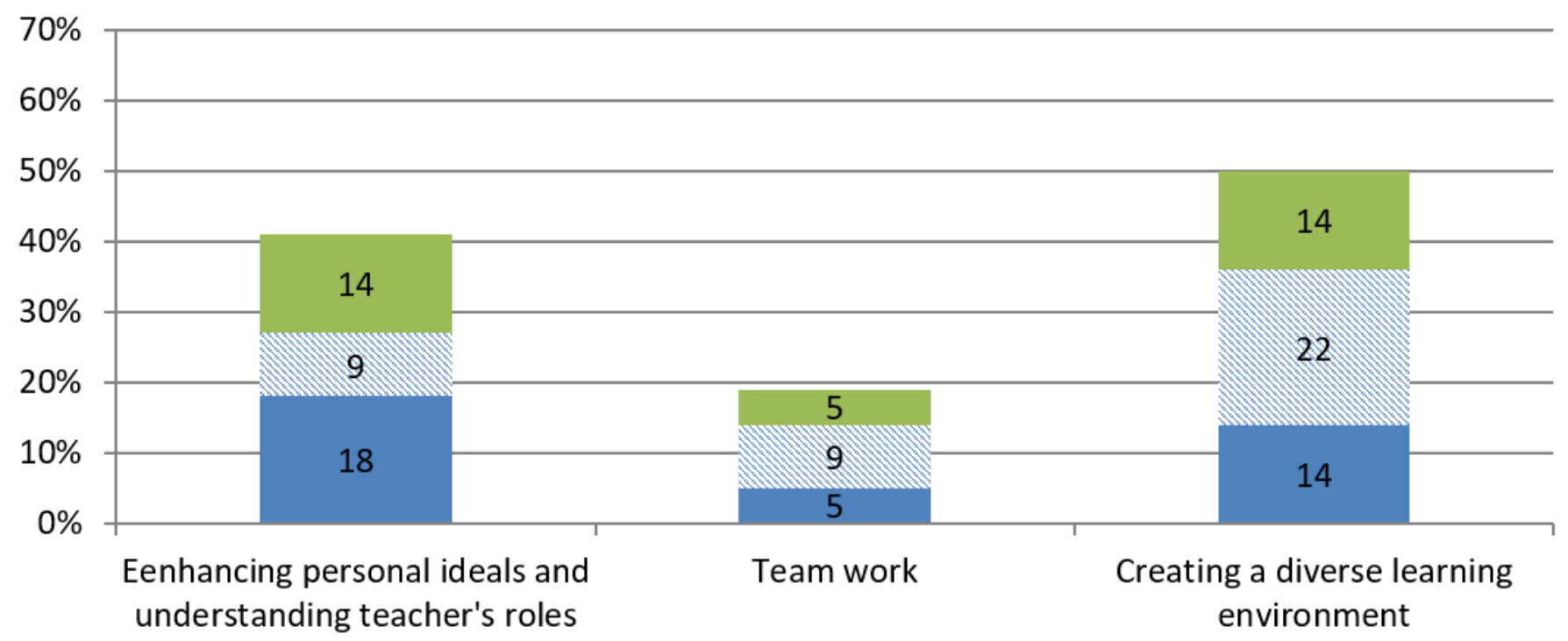

\section{Amount of times teachers ranked ' 3 ' $₫$ Amount of times teachers ranked ' 2 '}

\section{Amount of times teachers ranked ' 1 '}

Figure $3 \mathrm{~b}$. Teachers' ranking of identity resources in the Views program - Learning environment and personal beliefs category

roles. In addition, discussing their personal ideals and one's mission in becoming a novice teacher with their peers, supported their process of nurturing identity as novice chemistry teachers.

In the following section, we outline the experience of our three case study Views graduate novice chemistry teachers during their first years as chemistry teachers and provide details of specific practices they perceived as supportive of their teaching processes.

\section{Valuing competency-focused practices}

Yasmin is a 30-year-old second career novice teacher, who started to teach chemistry in high school three years ago. In her first career, Yasmin worked as a chemical engineer in the pharmaceutical industry. Yasmin's image of herself as a chemistry teacher stemmed from her vision that the teaching profession is highly demanding, requiring a lot of self-confidence for teaching chemistry and high levels of specialized pedagogical knowledge. Therefore, in addition to being a content expert, in order for her transition to the teaching profession to be successful, she needed pedagogical foundations, resources, and tools. Therefore, Yasmin appreciated the content knowledge taught in the program, which, combined with her newlyacquired pedagogical knowledge, provided her with a strong foundation of pedagogical content knowledge. For Yasmin, dedicating time for teaching the chemistry content knowledge instilled confidence in her and enabled her to diversify her teaching styles. She said: "...everyone assumes that having a first degree in chemistry means I obviously know chemistry, but it's really not like that... the subject I had learned and worked with in my first career, by and large, did not relate to what we are learning [at the Views program] and what we are required to teach in high school ... Here, chemistry was taught explicitly, and this saved me when I started teaching."

Trying to understand how this aspect helped her in the transition to the classroom as a teacher, she emphasized that "teaching the basics of chemistry and enriching the content knowledge beyond the curriculum enabled me to feel comfortable in the classroom. I particularly remember solving in 'real time' the matriculation exam that high school students must pass at the end of their chemistry studies. It helped me a lot to be in the position of the students and understand what is required of them."

For Yasmin, teaching the content knowledge was important, because she perceived this aspect as being the starting point of her teaching. This reflects her pedagogical view on her professional identity, that content knowledge centeredness is vital, as it enhances the teacher's sense of self-confidence in front of the classroom. Furthermore, she shared: "I was waiting for students to ask me interesting questions I didn't have the answer to... as I would do in my previous job, I would advise and help them to investigate the chemical concept behind their question and present their answer to the class." We can see that Yasmin builds and shapes her professional identity based on her previous experience in her first career regarding her abilities to teach and help her students navigate through the world of chemistry. She is not afraid to be wrong or not to know the answer; on the contrary, she embraces the fact that the teacher is not necessarily or always the main source of knowledge, and encourages her students to be independent learners. 
Curcumin is a bright yellow chemical produced by Curcuma longa plants. Chemically, curcumin is a diarylheptanoid, belonging to the group of curcuminoids which are natural phenols responsible for the turmeric's yellow color. Curcumin has been shown to target multiple signaling molecules while also demonstrating activity at the cellular level, which has helped to support its multiple health benefits. It has been shown to benefit inflammatory conditions, metabolic syndrome, pain, and to help in the management of inflammatory and degenerative eye conditions. The structural formula of curcumin is:
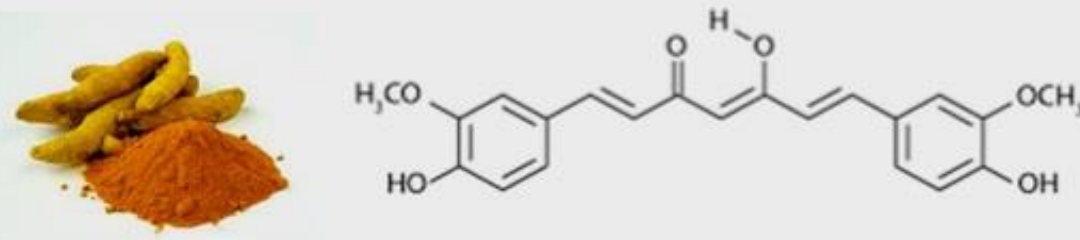

Conduct an experiment of curcumin solubility in two solvents. water and ethanol, $\mathrm{C}_{2} \mathrm{H}_{5} \mathrm{OH}_{(\mathrm{aq}}$.

\begin{tabular}{|c|c|c|}
\hline Question & Thinking skills & Category \\
\hline $\begin{array}{l}\text { Explain the results you } \\
\text { received from the } \\
\text { experiment, based on } \\
\text { what you saw and the } \\
\text { structure of Curcumin }\end{array}$ & $\begin{array}{l}\text { - Application of students' } \\
\text { knowledge about solubility } \\
\text { - Transfer from symbol to } \\
\text { microscopic level }\end{array}$ & \multirow{3}{*}{$\begin{array}{l}\text { - Chemistry understanding levels: } \\
\text { macroscopic, microscopic and } \\
\text { symbol } \\
\text { - Context based learning: curcumin } \\
\text { as a common used product in } \\
\text { food and medicine industry } \\
\text { - Involves active learning and } \\
\text { engagement from the students } \\
\text { - Aligned with the curriculum: } \\
\text { solubility and chemical bonding } \\
\text { - Interdisciplinary: chemistry and } \\
\text { biological aspects }\end{array}$} \\
\hline $\begin{array}{l}\text { Plan a follow-up } \\
\text { experiment and an } \\
\text { investigation of the } \\
\text { health benefits of } \\
\text { Curcumin }\end{array}$ & $\begin{array}{l}\text { - Question posing, } \\
\text { - Hypothesis formulating, } \\
\text { - Synthesis of previous } \\
\text { results in the first } \\
\text { experiment }\end{array}$ & \\
\hline $\begin{array}{l}\text { If we want to add } \\
\text { Curcumin to our food } \\
\text { as a spice for cooked } \\
\text { meals. Would you } \\
\text { advice to cook } \\
\text { Curcumin in water or } \\
\text { in oil? }\end{array}$ & $\begin{array}{l}\text {-Application of previous } \\
\text { chemical knowledge } \\
\text { - Synthesis of results in the } \\
\text { activity }\end{array}$ & \\
\hline
\end{tabular}

Figure 4. Analysis of Yasmin's designed assignment

Yasmin emphasized her need to learn how to teach a specific chemistry topic in different ways ways that are suitable for different types of learners: "Learning how to implement a variety of teaching tools and their relation to the topic I want to teach was very useful for me. I know how to plan a series of lessons on a particular topic using a variety of teaching and assessment tools, addressing the heterogeneity of students' needs." She wanted to tailor her teaching pedagogy first to the subject she taught, and later to the different levels of her students in order to motivate them to be active participants in the learning process (see Figure 4). She reflected: "Connecting chemistry to everyday experiences, learning in context, practicing inquiry as students, and reflecting on all of those activities helped me understand how I can best implement these methods in my classroom and engage my students in meaningful learning".

We can see that the learning needs of Yasmin focused on different content and pedagogical competencies with the aim of making chemistry learning relevant for her students and to motivate them to ask questions and to evolve as scientists. She perceives herself as a teacher who is involved with the learning process of her students, someone who motivates her students to learn and explore chemistry, and is aware of their learning needs. She is always willing to try different teaching methods, design a variety of learning activities, and adopt different classroom management approaches to foster students' learning process. Another aspect Yasmin emphasized was the technological knowledge she had been exposed to during the Views program. She expressed that "Nowadays, a teacher cannot enter the classroom without knowing and using technology. I would have liked to be exposed to more teaching technologies, especially in chemistry, due to the need to alleviate students' difficulty in understanding the microscopic level." Learning how to use technology as a pedagogical tool served the purpose of implementing a meaningful learning process using the four chemistry understanding levels macroscopic, microscopic, symbol and process.

Yasmin designed the assignment titled Learning about Curcumin, in which students received a scientific text about the advantages of curcumin and the way we use it in everyday life. The students were required to read the text and conduct an experiment of curcumin solubility in two solvents: water and ethanol, $\mathrm{C}_{2} \mathrm{H}_{5} \mathrm{OH}_{(\mathrm{aq})}$. Figure 4 presents analysis of some of the questions in the assignment. 
Yasmin's assignment begins with presenting the students a phenomenon in the macroscopic level (solubility of curcumin), and continues with questions that require students' explanations and observations in the microscopic and symbol levels. In the next stage, the students are asked to plan a follow-up experiment, enhancing their inquiry skills such as question posing ability. At the last stage, the assignment incorporates transferring their knowledge to every-day life situations such as cooking with curcumin. To answer this question, students must apply their previous knowledge within this new context while implementing the results they received in the initial stage of the assignment.

\section{Valuing teaching practices over theoretical coursework}

Tiffany is a 35 year-old second career teacher who worked as a researcher in an academic institute and as a teaching assistant (TA) in her previous career. Being a TA exposed Tiffany to the teaching profession and motivated her to join the Views program and to pursue a new career as a chemistry teacher. She talked about her experiences as a TA, and claimed that "the feeling of succeeding in explaining the material, the positive feedback from my students and the satisfaction after each lesson, made me think about a future career in the teaching profession". She emphasized the importance of practicing chemistry in real-life situations, such as working with the studentteachers as 'real-teachers' during the Views program. She also mentioned that implementing activities and tasks from the teachers' previous occupation and working setting for supporting their transition into the school system. According to her perception, additional teaching practice would have facilitated her comprehension of how to teach and manage a classroom, and what are the teachers' everyday tasks and routines. She reflects: "In retrospect, I understand I did not spend enough time in the classroom to comprehend everything that comes with it. I would like more practical experience in the classroom and less 'pretend play' ... for example, actually teaching a laboratory class to high school students ... As a teacher, it was difficult for me to cope with 20 students in one laboratory." Although Tiffany experienced teaching as a TA, it was different than teaching high school students. When they transition into the classroom, Tiffany realized that teaching does not only mean to serve as an instructor in the classroom (similar to what she had experienced as a TA), but also to manage the class and deal with other tasks outside the classroom. In her view, the teaching practice component of the Views program did not feel 'genuine.' She emphasized that learning to teach requires opportunities to engage with others-colleagues, students and mentors - in order to develop a structure that includes one's own perspectives and positions related to teaching. In other words, Tiffany's identity is constructed by positioning herself through active participation in meaningful activities that comprise her 'self' as a teacher.
It was apparent that her professional identity is highly influenced by the knowledge and skills she acquired in her first career as a researcher and a TA, but the process of linking this expertise to the classroom situation was challenging for her. The experience of being a TA contributed to her identity as an expert in the content knowledge and some knowledge in the pedagogy but she lacked practical tools to manage the classroom. She believed that the practice of teaching can help her transfer skills from her first career. She wanted the Views program to acknowledge her previous experiences as a scientist and to learn practical tools that would enable her to implement and present knowledge she could bring from her previous career. She shared: "Using my knowledge and experience to teach is the reason I came to the program. I believe this is the way to expose students to meaningful learning and to everyday life situations".

When transitioning to the classroom, Tiffany faced difficulties mainly because she wished to expand students' knowledge above and beyond the curriculum: "When I started teaching, I had a lot of ideas regarding the different teaching methods that I wanted to implement and topics I thought were important for the students to learn. As time passed, I realized that I was far behind in terms of the curriculum demands. I then felt very pressured to teach only what is required." She emphasized that "It is upsetting for me to see that the school system praises the pursuit of grades and adherence to the curriculum, without understanding what it means and how to learn meaningful science".

Tiffany's professional identity is characterized by her goal to motivate her students with her innovative ideas and expansive scientific worldview. She perceived herself as meaningful instructor who exposes her students to different concepts in chemistry, enriching their world beyond the curriculum, and showing them how to think and investigate like scientists.

This vision needed to be reshaped as she realized how the school system works and what it promotes. This collision of the two worlds forced her to reconcile her previous beliefs, which characterize her professional identity, with her new reshaped identity in the context of the school environment and its constraints. She mainly expressed feelings of frustration and disappointment with the fixation of the school environment in both the pedagogical aspect and the content that needed to be taught.

Tiffany designed an assignment as a game, activated by a software application (app). Players in this game seek a treasure through different stations, in which there are questions that must be answered correctly. When the student answers a question, she receives clues to move forward to the next station and get closer to the treasure. Figure 5 presents an analysis of some of the questions in the assignment. 


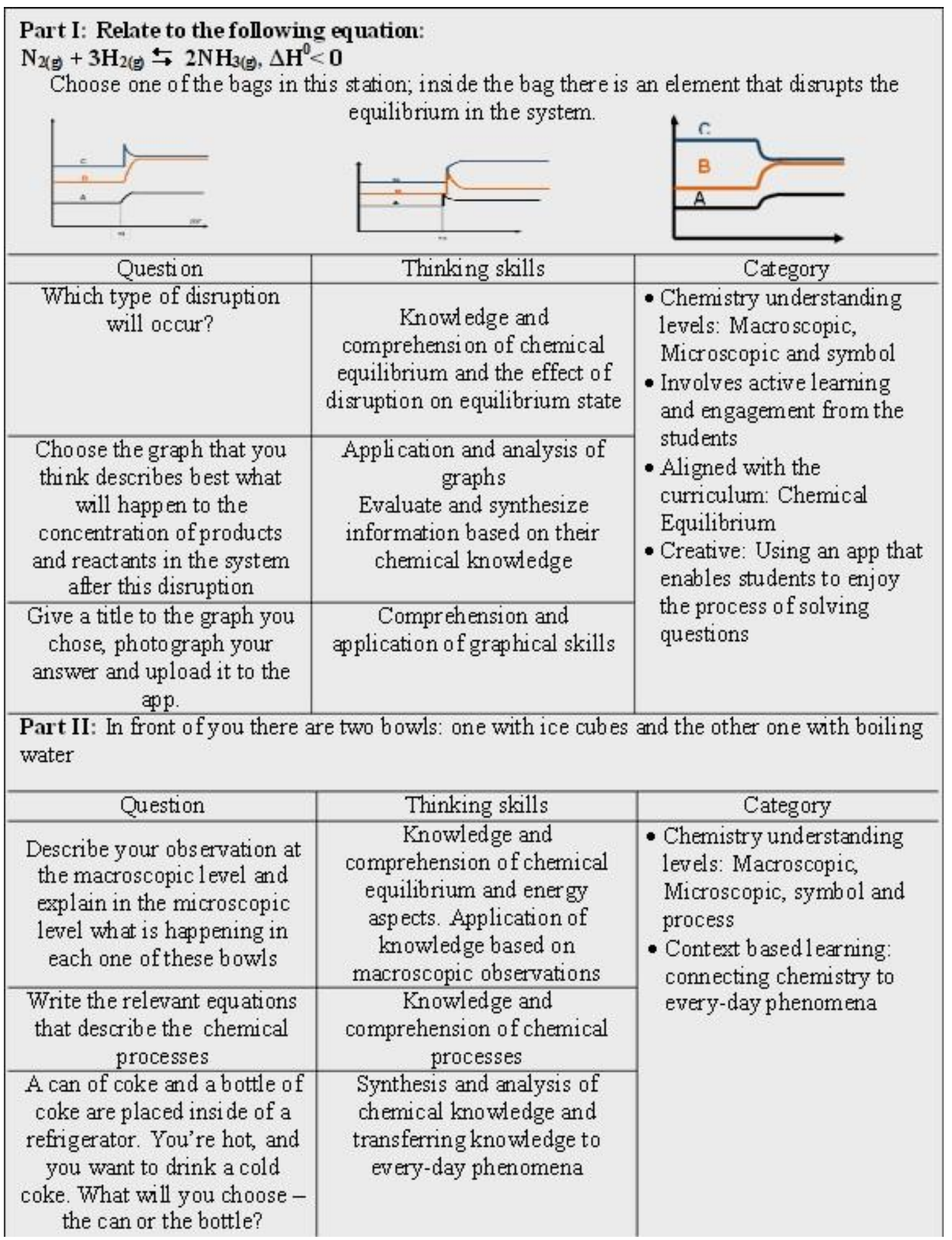

Figure 5. Analysis of Tiffany's designed assignment

\section{Enhancing mission and beliefs through teamwork and a diverse learning environment}

Phil is a 55-year-old second career novice teacher, who started to teach chemistry in middle school two years ago and later transitioned into high school. In his first career, Phil worked in high-tech as a project manager and a consultant in the food sector. Phil expressed a dedication for his mission and personal ideals when describing his decision to transition into the teaching profession. For him, it was a "mission to influence the next generation and contribute to adolescents from his own knowledge and experiences". He related to his mission as desire to achieve two things: (1) pass on to his students both his knowledge and concepts in the chemistry subject matter and his motivation to study chemistry; and (2) help young people. Phil portrayed high intrinsic motivation and his perception about his image as a teacher stemmed from his desire to contribute to the educational system from the knowledge and skills he acquired in his previous career. He exhibited selfconfidence in his goals, capabilities, and desire to teach. 
He emphasized that his beliefs about what it means to be a teacher were reshaped during the program due to the creation of a diverse learning environment and teamwork. The social aspect in Phil's case was prominent for shaping his professional identity as a teacher. Through interactions, discussions and engaging with others, he realized what kind of teacher he would like to be. He described the relationship with his peers while sharing knowledge when they worked together: "The combination of a variety of student types who study together after they chose teaching as first-or second career created a solid knowledge base, where each [participant] could contribute in his [or her] own way".

In Phil's perception, the unique learning environment in the Views program enabled him to communicate with others about professional and pedagogical knowledge and practices, as well as beliefs and perception of what it means to be a teacher: "I am used to working in teams from my previous job, but I felt that it was different, because I felt comfortable sharing my point of view and listening to others' views and approaches to teaching... It was an open space for me to express myself." During the program, teachers collaborated and discussed in groups, planned lessons together, presented materials to each other, and reflected on these lessons. This teamwork enabled Phil to learn from others about different pedagogies and to brainstorm about best practices that are suitable for specific chemistry topics. Therefore, when integrating into the school system, he expected this kind of support and collaboration from his colleagues. He emphasized his desire for colleagues' and mentors' support by getting help with his transition process by planning lessons together, watching his lessons, and giving feedback. His meaning of support related to having colleagues who appreciated his life experience and knowledge, and support his desire to implement innovative ideas in the school environment and in his classroom. Phil needed acknowledgment from by others that he brings to the teaching valuable and relevant skills and practices, gained in his previous career. His need to receive feedback from others, along with social interactions and personal experiences, created an identity of a leader who has a vision, a coherent understanding of his role, practice, and selfreflection. He talked at length about projects and ideas he wanted to integrate into his chemistry lessons but were rejected by his colleagues. For example "I wanted to do something new in school to promote chemistry so that more students will choose to major in chemistry. I brought new ideas to my colleague, who teaches chemistry with me, and she resisted every idea; I didn't get any cooperation from her at all. It was like she didn't want to accept anything I suggested. It really made me wonder what I was doing wrong." We can see that Phil not only engages in the practice of leadership; he also identifies himself as a teachers' leader.

In his assignment, Phil presented an activity of inquiry he had designed and implemented in the classroom using sensors and software to investigate the changes in conductivity while at different concentrations of $\mathrm{NaOH}_{(\mathrm{aq})}$ and $\mathrm{CuCl}_{2(\mathrm{aq})}$ solutions. The assignment included observations at the macroscopic level, identifying the sedimentation reaction and writing the equation, analyzing the online-generated graph, and explaining the changes in conductivity at the microscopic level. He said that "the idea of using the software and combining our content knowledge with pedagogical and technological knowledge challenged me, but I was happy to get out of my comfort zone. Only after preparing the activity and conducting the discussion with the peers in the course, I understood the potential and advantages of using technology in the classroom." Figure 6 presents an analysis of some of the questions in Phi's assignment.

\section{DISCUSSION}

In this study, we used identity as a theoretical framework to understand the transition process of second career teachers into the teaching profession as they navigate two major institutional contexts - their preparation program and the school system. The findings from this study resonate with the teacher identity development literature and add to it by providing detailed description on how second career novice teachers perceive themselves while creating a new identity of a teacher.

A professional identity perspective provides a holistic view, through which the teacher presents both his/her personality and expertise. Analysing the interviews, questionnaires and the designed assignment of the teachers' case studies created a unique narrative for each teacher, but at the same time revealed commonalities and differences regarding explicit and implicit foundations in their preparation program and how it nurtures their identity as teachers. Yasmin perceived her professional 'self' by building on her competencies and pedagogical practices that were central to her teaching process. Tiffany leaned on her previous experience and searched for opportunities to engage with others through active participation in meaningful activities that comprise her 'self' as a teacher. Phil's self-perception was one of a leader with strong sense of mission and initiative.

The following principles were common to all case studies (Beauchamp \& Thomas, 2009; Olsen, 2016; Leshem, 2019; Richmond, 2016 ;van der Wal et al., 2019): (1) Teachers' expertise in their previous career was an essential part of their professional identity; it laid out the foundations for their new identity as teachers enabling them to build upon their previous career experiences and added new knowledge and qualities effectively. For example, Tiffany reflected on the importance of transferring her skills from her first career to the teaching profession, while integrating new pedagogical methods acquired in the program, (2) Second career teachers 


\begin{tabular}{|c|c|c|}
\hline \multicolumn{3}{|c|}{$\begin{array}{l}\text { In this inquiry activity you will work in teams and use } \mathrm{pH} \text { and conductivity sensors in } \\
\text { order to investigate the effect of } \mathrm{NaOH} \text { concertation on the } \mathrm{CuCl}_{2} \text { volume that is } \\
\text { added until the formation of the sediment? }\end{array}$} \\
\hline 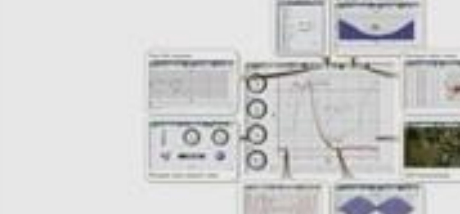 & 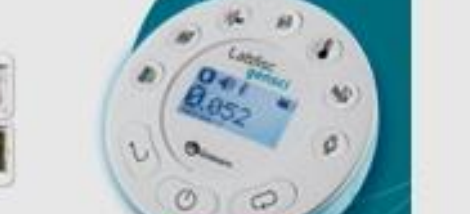 & \\
\hline Question & Thinking skills & \multirow{7}{*}{$\begin{array}{l}\text { - Chemistry } \\
\text { understanding levels: } \\
\text { Macroscopic, } \\
\text { Microscopic, symbol and } \\
\text { process } \\
\text { - Involves active learning } \\
\text { and engagement from } \\
\text { the students } \\
\text { - Creative: using } \\
\text { technological tools and } \\
\text { sensors to determine the } \\
\text { titration end point } \\
\text { - Aligned with the } \\
\text { curriculum: ionic } \\
\text { compounds solubility }\end{array}$} \\
\hline $\begin{array}{l}\text { Define the independent and } \\
\text { dependent variables in this } \\
\text { experiment }\end{array}$ & $\begin{array}{l}\text { Knowledge and } \\
\text { comprehension of the } \\
\text { research process }\end{array}$ & \\
\hline $\begin{array}{l}\text { Formulate an hypothesis } \\
\text { based on your chemical } \\
\text { knowledge }\end{array}$ & \multirow[t]{2}{*}{$\begin{array}{l}\text { Application and analysis of } \\
\text { chemical knowledge about } \\
\text { ionic compounds solubility }\end{array}$} & \\
\hline $\begin{array}{l}\text { Formulate the sediment } \\
\text { formation reacti on }\end{array}$ & & \\
\hline $\begin{array}{c}\text { What were the limitations in } \\
\text { this experiment? }\end{array}$ & \multirow{2}{*}{$\begin{array}{l}\text { Synthesis and analysis of } \\
\text { the inquiry activity and } \\
\text { demonstrating critical } \\
\text { thinking }\end{array}$} & \\
\hline $\begin{array}{l}\text { What are your insights about } \\
\text { the titration method? }\end{array}$ & & \\
\hline $\begin{array}{l}\text { Write another research } \\
\text { questi on you would like to }\end{array}$ & Question $\mathrm{p}$ & \\
\hline
\end{tabular}

Figure 6. Analysis of Phil's designed assignment

brought to the teaching profession a strong sense of mission and came with high intrinsic motivation. Yasmin, Tiffany and Phil emphasized their willingness to contribute to their students from their knowledge and life experience. This result resonates with HunterJohnson's study (2015) who examined motivational factors that influence career changers' decision to teach. Results showed that participants were intrinsically motivated to serve as agents of change and exhibited passion for the teaching profession, (3) Teachers exhibited self-confidence in their teaching capabilities and were outspoken with respect to their vision and future plans as teachers. They were clear regarding their need to acquire practical tools that they can implement in the classroom and use to motivate their students to become active learners. Hence, they understood that having a deep content knowledge can be irrelevant for them if they are unable to explain it to their students. Second career teachers' high sense of self-efficacy was documented in several studies; Troesch, and Bauer (2017) who investigated job satisfaction among second career teachers and the role of self-efficacy in this context, found that second career teachers have high selfefficacy beliefs. Avargil et al., (2020) found high selfefficacy in chemistry learning, teaching and in taskoriented aspects.
Comparing the high sense of confidence of career changers to first career teachers, we reveal inconsistent findings in the literature (Koedel et al., 2015; Dori, Tal, Goldman, Sarid, Lavie-Alon \& Shwartz, 2019). In the national-large scale study, we compared the effectiveness of preparation programs regarding the integration of first and second career teachers into the educational system; we found first and second career teachers did not differ in their self-efficacy in class and student management skills, which was high $(4.11 \pm 0.56)$. In contrast, second career teachers reported greater contribution of the program to their sense-ofpreparedness to function in professional aspects of teaching. Furthermore, the link between self-efficacy and contribution of the program to teaching skills is significantly stronger in second career teachers compared to first career teachers $(3.49 \pm 0.78$ and $2.92 \pm 0.84, \mathrm{t}=4.281, \mathrm{p}<.001$ ) (Dori, et al., 2019). Troesch, and Bauer (2017) found second career teachers have higher self-efficacy beliefs than first career teachers, (4) They needed acknowledgment from others in order to improve their skills that gained in their previous career, as in Phil's case, who strived for the recognition of his colleagues. Similarly Wilkin's (2017) study found that second career teachers felt being under-appreciated in their school environment by their colleagues making 
their transition more challenging, and (5) They had to revise their professional identity moving from one institutional context - the education program, to another - the school context; forcing its reconciliation through experiencing and overcoming challenges of various kinds (Pillen et al., 2013; Tigchelaar et al., 2014 ;van der Wal et al., 2019). Wilkin (2017) emphasized the main challenge for second career teachers as the transition from being an expert in one domain to novice in another. This challenge forced them to recognise that they had a lot to learn in their new role as novice teachers. Returning to our case study, Tiffany, saw herself as meaningful instructor and change agents, whose mission is to expose her students to different concepts in chemistry, enrich their world beyond the curriculum, and show them how to think and investigate like scientists. When exposed to the realities of how chemistry is taught practically in school, she faced the challenge of coping with an abundance of negative feelings, such as frustration and disappointment. Pillen and colleagues (2013) argued that it would be helpful if novice teachers are guided to give meaning to the negative feelings that accompany the challenges they experience. This proactive approach of facing the challenges that make teachers question their professional identity requires mentors in teacher preparation programs and colleagues in the school to encourage the teachers to recognize these challenges, discuss them, and help them cope with them (Ehrich et al., 2011). Moreover, teacher education programs can help teachers to turn these feelings into learning moments that will later shape their beliefs and enhance their professional identity (Pillen et al., 2013; Skott, 2019).

Although the teachers participated in the same teacher preparation program, each one of them attributed his/her identity development to other resources and practices implemented in the program. That said, the program mission, preparation standards, coursework, field experiences, and social contexts, all provided an opportunity to shape one's identity but they are not equal with respect to their ability to nurture identity (Luehmann, 2016). Some practices afford the learner more identity resources than others (Luehmann, $2007 ; 2009)$. We can see evidence to these resources in the ranking of teachers with regards to the aspects that supported their identity shaping and transition to school. For example, creating a diverse learning environment and enhancing personal ideals was ranked high, and in Phil's case increased his sense of initiative and leadership, and afforded him with more agency as a teacher; whereas in Yasmin's case, a variety of pedagogical and content resources increased her sense of confidence accountability for competence. On the contrary, practicing teaching, although ranked low set the ground for all case study teachers to be able to experience the teaching profession (not enough in their perception) in an authentic way and reconcile their identity with the new learning context, making this identity resource prominent and significant in teacher education programs. One possible explanation for these results is the age difference among participants. Focusing on our case studies, Yasmin as the youngest one, focused on building her confidence as a teacher by connecting her content knowledge with new pedagogical tools. She understood her students' difficulties and therefor the aspects in the competencies category were more central to her identity. Phil, on the other hand, the older one, with a vast of experience and confidence, focused on motivating and helping his students to think outside the box as if they were 'scientists'. His reshaped identity was drawn from the ideals and sense of mission discussed in the program.

We also learned that it is through the active participation, within the unique learning environment of the program, and through the different aspects we mapped as vital for the teacher's identity, one's understanding and vision of the particular kind of teacher one aspires to be, develops and reshapes. Tsybulsky and Muchnik-Rozanov (2019) examined the development of professional identity of 17 pre-service teachers during their pedagogical practicum. They also emphasized the importance of meaningful experiences and active involvement of teachers in two dimensions: overcoming challenges and involvement in fruitful and supportive cooperation with their peers. Although teaching practice was ranked low, Tiffany emphasized in her interview the significance of this aspect to her 'self' as professional. Therefore, when a teacher is engaged in the work of pedagogical design, such as the assignments teachers designed and we analysed, we use this design as a tool for investigating the effectiveness and success of the identity resources implemented in the program (Nasir \& Hand, 2004). Analysing the assignments our case study teachers designed and their reflections in the questionnaire, we found that the technological and pedagogical content knowledge they had acquired during the program translated into their practice as teachers. Indeed, in their assignments the teachers integrated a variety of teaching methods and higher order thinking skills while connecting chemistry to everyday life, but each one of them implemented the specific identity resource, presented and implemented in the program, in its own authentic way. For example, Tiffany's assignment reflected her belief in diversifying chemistry learning with unique pedagogical tools. Phil's assignment showed he is not afraid to use technological tools and present applications to his colleagues. In Yasmin's assignment, the content and deep understanding of the chemical phenomena was in the centre. In further research, we plan to apply our questionnaire and teachers' designed-assignments with a larger research population from additional STEM disciplines, so that the quantitative aspect will provide a stronger evidence base for our findings. 


\section{Implications of the Study for Teacher Preparation Programs}

Second career teachers are a unique group of teachers with specific learning needs, beliefs, and professional identity (Tigchelaar et al., 2010; Unruh and Holt, 2010; Leshem, 2019). Recognizing these needs and caring for them will promote teachers' successful transition to the school system while nurturing their identity as professionals, satisfaction from the teaching profession, and retention (Lee and Lamport, 2011; Tigchelaar et al., 2010).

The current study suggests using identity resources, as the second career teachers reported and we present a lens for comparing the efficacy of different practices in attributing to one's identity and offer the following opportunities (Hammerness, 2005; Luehmann, 2009; 2016):

Engaging in critical discussions, reflection and feedback about practices and pedagogical views. As we have found, one's understanding and vision of the particular kind of teacher one aspires to be, develops and reshapes through active participation within the program's unique learning environment. The discussions, interactions, and negotiations carried out in this environment enable developing clear positions about beliefs and pedagogical standpoints in the teaching profession (Luehmann, 2016; Gracia et al., 2019; Richmond, 2016). Furthermore, we saw that career changers desire to contribute to society was the main impetus that drove their transition to the teaching profession. Indeed, the literature suggests that the reasons second career teachers choose such a career change are mostly due to their high levels of intrinsic motivation; they are driven by a desire to pass on their expertise and contribute to humanity (Lee and Lamport, 2011; Powers, 2002). To ensure that second career teachers' transition is successful, we need to expose them to different educational systems and reflecting over them, prior to their transition, giving them the opportunity to modify and reshape their perceptions, beliefs and professional identity of what it means to be a teacher.

Practicing teaching in 'real-life' and authentic situations over long term and sustained ways to understand teachers' role. Although ranked low, the case study teachers perceived this identity resource as the one that may have provided the most support in their transition into the teaching profession, enabling them to practice real-life situations, such as working with students and implementing pedagogical innovations (Sinha, \& Hanuscin, 2017). Furthermore, this 'real-time' teaching will encourage them to transfer their first career experiences into the teaching profession, allow preservice teachers to become familiar with the workload of teachers (Casey et al., 2013) , and possibly avoid a reality shock when transitioning into the school system
(Priyadharshini \& Robinson-Pant, 2003). Novice teachers, who have less field experience, feel less prepared than novice teachers whose preparation includes more field experience (Kee, 2012). However, the literature does not specify the amount and quality of teaching practice teachers need in order to make them feel ready to enter the classroom.

Enhancing the integration of career changers' expertise in their previous career. The second career teachers bring to their classrooms valuable and transferable skills, primarily practical expertise and realworld knowledge. Hence, connecting this expertise to classroom situations can be challenging (Tigchelaar et al., 2010; Tigchelaar et al., 2014; Lee and Lamport, 2011). To improve this deficiency, second career teacher preparation programs should recognize and acknowledge teachers' first career's past experiences and skills and include active and explicit exploration of these experiences. This includes addressing the curricula, teaching and assessment methods, mastering educational technologies, and implementing this multidomain knowledge during the teaching process. In other words, these programs should aim at combining and effectively fusing content knowledge, pedagogical content knowledge, and technological knowledge into technological pedagogical content knowledge. Another aspect is creating a diverse learning environment, where teachers share their ideas and experiences, enhance personal relationship, discuss, negotiate and strengthen their understanding that they are part of a community that supports and learns from each other (Baeten \& Meeus, 2016; Gracia et al., 2019).

Providing opportunities for meaningful recognition by others. In Phil's case, he strived for the recognition of his colleagues in his life experience and ability to lead his students to success. By recognizing second career teacher characteristics, teacher preparation programs should view these teachers as partners in the learning process, encourage them to take a stand, initiate, include their specific needs during the program, and enable them to make decisions related to different teaching and learning aspects (Sinha, \& Hanuscin, 2017).

\section{Contributions and Implications}

Our research has theoretical and practical contributions. As evident from our findings and supported by other studies, context plays an important role in teacher identity development. At the theoretical level, we used an identity lens to understand career changers' transition process in a critical point of their career pathway - from a preparation program into the school.

Practically, with respect to career transition from industry to teaching, we suggest guidelines to school administrators for improving chemistry professionals' 
shift from their previous career into their second career as teachers in ACP. Our results indicated the tensions in identity created within teachers' 'self' perception when starting to teach. Principals, mentors and other administrators should strive to create constructive environments within schools for second career teachers. This will require administrators to be aware and considerate of the unique vision, skills and the previous experience of the second career teachers. They should encourage teachers to implement innovative teaching methods, include them in various decision-making procedures regarding school issues, and give recognition to the expertise they bring forth from their first career.

\section{ACKNOWLEDGEMENT}

The generous financial help of the Israel Science Foundation - \#1725/16, and the Irwin and Joan Jacobs Graduate School, Technion - Israel Institute of Technology is gratefully acknowledged.

\section{REFERENCES}

Antink-Meyer, A., \& Brown, R. A. (2017). Second-career science teachers' classroom conceptions of science and engineering practices examined through the lens of their professional histories. International Journal of Science Education, 39(11), 1511-1528. https:/ / doi.org/10.1080/09500693.2017.1338787

Avalos, B., \& De Los Rios, D. (2013). Reform environment and teacher identity in Chile. In Education, dominance and identity (pp. 151-175). Brill Sense.

https:/ / doi.org/10.1007/9789462091252_011

Avargil, S., Kohen, Z., \& Dori, Y. J. (2020). Trends and perceptions of choosing chemistry as a major and a career. Chemistry Education Research and Practice, 21(2), 668-684. https://doi.org/10.1039/ C9RP00158A

Avargil, S., Herscovitz, O., \& Dori, Y. J. (2012). Teaching thinking skills in context-based learning: Teachers' challenges and assessment knowledge. Journal of science education and technology, 21(2), 207-225. https: / / doi.org/10.1007/s10956-011-9302-7

Baeten, M., \& Meeus, W. (2016). Training second-career teachers: a different student profile, a different training approach?. Educational process: international journal, 5(3), 173-201. https://doi.org/10.13973/ edupij.2016.53.1

Beauchamp, C., \& Thomas, L. (2009). Understanding teacher identity: An overview of issues in the literature and implications for teacher education. Cambridge journal of education, 39(2), 175-189. https://doi.org/10.1080/03057640902902252

Beijaard, D., Meijer, P. C., \& Verloop, N. (2004). Reconsidering research on teachers' professional identity. Teaching and teacher education, 20(2), 107128. https:/ / doi.org/10.1016/j.tate.2003.07.001

Beltman, S., Glass, C., Dinham, J., Chalk, B., \& Nguyen, B. (2015). Drawing identity: Beginning pre-service teachers' professional identities. Issues in Educational Research, 25(3), 225.

Buldur, S. (2017). A longitudinal investigation of the preservice science teachers' beliefs about science teaching during a science teacher training programme. International Journal of Science Education, 39(1), 1-19. https://doi.org/10.1080/ 09500693.2016.1262084

Casey, P., Dunlap, K., Brister, H., Davidson, M., \& Starrett, T. M. (2013). Sink or swim? Throw us a life jacket! Novice alternatively certified bilingual and special education teachers deserve options. Education and Urban Society, 45(3), 287-306. https:/ / doi.org/10.1177/0013124511408075

Creswell, J. W., Hanson, W. E., Clark Plano, V. L., \& Morales, A. (2007). Qualitative research designs: Selection and implementation. The counseling psychologist, 35(2), 236-264. https://doi.org/ $10.1177 / 0011000006287390$

Creswell, J. W. (2002). Educational research: Planning, conducting, and evaluating quantitative (pp. 146-166). Upper Saddle River, NJ: Prentice Hall.

Darling-Hammond, L. (2017). Teacher education around the world: What can we learn from international practice?. European journal of teacher education, 40(3), 291-309. https:/ / doi.org/10.1080/02619768.2017.1315399

Diekman, A. B., \& Benson-Greenwald, T. M. (2018). Fixing STEM workforce and teacher shortages: How goal congruity can inform individuals and institutions. Policy Insights from the Behavioral and Brain Sciences, 5(1), 11-18. https://doi.org/ $10.1177 / 2372732217747889$

Dori, Y. J., Tal, T., Goldman, D., Sarid, A., Lavie-Alon, N. \& Shwartz, G. (2019). Alternative certification teachers' education programs: Characteristics of graduate`s integration into the school system. Chief Scientist, Ministry of Education, Israel. https: / / edu.gov.il/sites/ChiefScientist/ ongoingr esearches/ongoingresearches/Pages/preservice.a $\operatorname{spx}$

Eifler, K., \& Potthoff, D. E. (1998). Nontraditional teacher education students: A synthesis of the literature. Journal of Teacher Education, 49(3), 187-195. https:/ / doi.org/10.1177/0022487198049003004

Etherington, M. (2009). Swapping the boardroom for the classroom. Australian Journal of Teacher Education (Online), 34(4), 39.

Ehrich, L. C., Kimber, M., Millwater, J., \& Cranston, N. (2011). Ethical dilemmas: A model to understand teacher practice. Teachers and Teaching: theory and 
practice, 17(2), 173-185. https://doi.org/10.1080/ 13540602.2011.539794

Fraenkel, J. R., Wallen, N. E., \& Hyun, H. H. (2011). How to design and evaluate research in education. New York: McGraw-Hill Humanities/Social Sciences/Languages.

Fry, S. W., \& Anderson, H. (2011). Career changers as first-year teachers in rural schools. Journal of Research in Rural Education.

Gracia, E. P., Rodríguez, R. S., \& Pedrajas, A. P. (2019). Analysis of Science and Technology pre-service teachers' beliefs on the construction of the Teachers' Professional Identity during the initial training process. EURASIA Journal of Mathematics, Science and Technology Education, 15(10), em1756. https:// doi.org/10.29333/ejmste/105896

Gee, J. P. (2000). Chapter 3: Identity as an analytic lens for research in education. Review of research in education, 25(1), 99-125. https://doi.org/10.3102/ 0091732X025001099

Glaser, B. G., \& Strauss, A. L. (2017). Discovery of grounded theory: Strategies for qualitative research. Routledge.

Hammerness, K. (2005). How teachers learn and develop. Preparing teachers for a changing world, 358389.

Hazzan, O., Heyd-Metzuyanim, E., Even-Zahav, A., Tal, T., \& Dori, Y. J. (2018). STEM Teachers' SWOT analysis of STEM education: The bureaucraticprofessional Conflict. In Application of Management Theories for STEM Education (pp. 1-23). Springer, Cham. https://doi.org/10.1007/978-3-319-689500_1

Hazzan, O., \& Ragonis, N. (2014). STEM teaching as an additional profession for scientists and engineers: the case of computer science education. Proceedings of the 45th ACM technical symposium on Computer science education, ACM. https://doi.org/10.1145/ 2538862.2538879

Horn, I. S., Nolen, S. B., Ward, C., \& Campbell, S. S. (2008). Developing practices in multiple worlds: The role of identity in learning to teach. Teacher Education Quarterly, 35(3), 61-72.

Hunter-Johnson, Y. (2015). Demystifying the mystery of second career teachers' motivation to teach. The Qualitative Report, 20(8), 1359.

Jonsen, K., \& Jehn, K. A. (2009). Using triangulation to validate themes in qualitative studies. Qualitative Research in Organizations and Management: An International Journal, 4(2), 123-150. https://doi.org/10.1108/17465640910978391

Katz, P., McGinnis, J. R., Hestness, E., Riedinger, K., Marbach-Ad, G., Dai, A., \& Pease, R. (2011). Professional identity development of teacher candidates participating in an informal science education internship: A focus on drawings as evidence. International Journal of Science Education, 33(9), 1169-1197. https://doi.org/10.1080/ 09500693.2010.489928

Kee, A. N. (2012). Feelings of preparedness among alternatively certified teachers: What is the role of program features? Journal of Teacher Education, 63(1), 23-38. https://doi.org/10.1177/ 0022487111421933

Koedel, C., Parsons, E., Podgursky, M., \& Ehlert, M. (2015). Teacher preparation programs and teacher quality: Are there real differences across programs?. Education Finance and Policy, 10(4), 508534. https:/ / doi.org/10.1162/EDFP_a_00172

Koeppen, K. E., \& Griffith, J. B. (2003). Nontraditional Students and Their Influence on Teacher Education. Paper presented at the American Association of Colleges for Teacher Education Annual Conference, New Orleans.

Lasky, S. (2005). A sociocultural approach to understanding teacher identity, agency and professional vulnerability in a context of secondary school reform. Teaching and teacher education, 21(8), 899-916. https:// doi.org/10.1016/j.tate.2005.06.003

Lee, E. D., \& Lamport, A. (2011). Non-traditional entrants to the profession of teaching: Motivations and experiences of second-career educators. Christian Perspectives in Education, 4(2), 3.

Leshem, S. (2019). Envisioning the future: second career teachers' hopes and concerns. International Journal of Teaching and Education, 7(1), 56-72.

Luehmann, A. (2016). Practice-Linked Identity Development in Science Teacher Education: GET REAL! Science as a Figured World. In Studying Science Teacher Identity (pp. 15-47). Brill Sense.

Luehmann, A. L. (2009). Accessing resources for identity development by urban students and teachers: Foregrounding context. Cultural Studies of Science Education, 4(1), 51-66. http://doi.org/10.1007/ s11422-008-9139-4

Luehmann, A. L. (2007). Identity development as a lens to science teacher preparation. Science education, 91(5), 822-839. https:/ / doi.org/10.1002/ sce.20209

Marshall, C., \& Rossman, G. B. (2014). Designing qualitative research. Sage publications.

McCaslin, M. (2009). Co-regulation of student motivation and emergent identity. Educational Psychologist, 44(2), 137-146. https://doi.org/ $10.1080 / 00461520902832384$

Nasir, N. I., \& Hand, V. (2004). From the court to the classroom: Managing identities as learners in basketball and classroom mathematics. In annual meeting of the American Educational Research Association, San Diego, CA. 
Olsen, B. (2016). Teaching for success: Developing your teacher identity in today's classroom. Routledge.

Pillen, M., Beijaard, D., \& Brok, P. D. (2013). Tensions in beginning teachers' professional identity development, accompanying feelings and coping strategies. European Journal of Teacher Education, 36(3), 240-260. https://doi.org/10.1080/ 02619768.2012 .696192

Powers, F. W. (2002). Second-career teachers: Perceptions and mission in their new careers. International Studies in Sociology of Education, 12(3), 303-318.

https:/ / doi.org/10.1080/09620210200200095

Priyadharshini, E., \& Robinson-Pant, A. (2003). The attractions of teaching: An investigation into why people change careers to teach. Journal of Education for Teaching, 29(2), 95-112. https://doi.org/ $10.1080 / 0260747032000092639$

Richardson, P. W., \& Watt, H. M. (2006). Who chooses teaching and why? Profiling characteristics and motivations across three Australian universities. Asia-Pacific Journal of Teacher Education, 34(1), 27-56. https:/ / doi.org/10.1080/13598660500480290

Richmond, G. (2016). Making sense of the interplay of identity, agency, and context in the development of beginning science teachers in high-poverty schools. In Studying science teacher identity (pp. 219-235). SensePublishers, Rotterdam. https://doi.org/ 10.1007/978-94-6300-528-9_11

Richmond, G., Juzwik, M. M., \& Steele, M. D. (2011). Trajectories of teacher identity development across institutional contexts: Constructing a narrative approach. Teachers College Record, 113(9), 1863-1905.

Ritchie, J., Lewis, J., \& Elam, G. (2003). Designing and selecting samples (pp. 77-108). London: Sage.

Sinha, S., \& Hanuscin, D. L. (2017). Development of teacher leadership identity: A multiple case study. Teaching and Teacher Education, 63, 356-371. https://doi.org/10.1016/j.tate.2017.01.004

Salta, K., Gekos, M., Petsimeri, I., \& Koulougliotis, D. (2012). Discovering factors that influence the decision to pursue a chemistry-related career: A comparative analysis of the experiences of non scientist adults and chemistry teachers in Greece. Chemistry Education Research and Practice, 13(4), 437446. https:/ / doi.org/10.1039/C2RP20053H

Skott, J. (2019). Changing experiences of being, becoming, and belonging: Teachers' professional identity revisited. ZDM, 51(3), 469-480. https:/ / doi.org/10.1007/s11858-018-1008-3

Slavich, G. M., \& Zimbardo, P. G. (2012). Transformational teaching: Theoretical underpinnings, basic principles, and core methods. Educational psychology review, 24(4), 569-608. https:/ / doi.org/10.1007/s10648-012-9199-6
Snyder, C., Oliveira, A. W., \& Paska, L. M. (2013). STEM career changers' transformation into science teachers. Journal of Science Teacher Education, 24(4), 617-644. https://doi.org/10.1007/s10972-0129325-9

Stake, R. E. (2013). Multiple case study analysis. Guilford Press.

Tigchelaar, A., Vermunt, J. D., \& Brouwer, N. (2014). Patterns of development in second-career teachers' conceptions of teaching and learning. Teaching and teacher education, 41, 111-120. https://doi.org/ $10.1016 /$ j.tate.2014.04.001

Tigchelaar, A., Brouwer, N., \& Vermunt, J. D. (2010). Tailor-made: Towards a pedagogy for educating second-career teachers. Educational Research Review, 5(2), 164-183. https://doi.org/10.1016/j.edurev. 2009.11.002

Trent, J. (2018). 'Fitting in'or 'being different'? Integration, separation, and identity construction during a teaching practicum in Hong Kong. Teacher Development, 22(4), 571-586. https://doi.org/ 10.1080/13664530.2018.1466722

Treagust, D. F., Won, M., Petersen, J., \& Wynne, G. (2015). Science teacher education in Australia: Initiatives and challenges to improve the quality of teaching. Journal of Science Teacher Education, 26(1), 81-98. https:/ / doi.org/10.1007/s10972-014-9410-3

Troesch, L. M., \& Bauer, C. E. (2017). Second career teachers: Job satisfaction, job stress, and the role of self-efficacy. Teaching and Teacher Education, 67, 389398. https:/ / doi.org/10.1016/j.tate.2017.07.006

Tsybulsky, D., \& Muchnik-Rozanov, Y. (2019). The development of student-teachers' professional identity while team-teaching science classes using a project-based learning approach: A multi-level analysis. Teaching and Teacher Education, 79, 48-59. https:// doi.org/10.1016/j.tate.2018.12.006

Unruh, L., \& Holt, J. (2010). First-year teaching experiences: Are they different for traditionally versus alternatively certified teachers?. Action in teacher education, 32(3), 3-14. https:/ / doi.org/10.1080/01626620.2010.10463555

van der Wal, M. M., Oolbekkink-Marchand, H. W., Schaap, H., \& Meijer, P. C. (2019). Impact of early career teachers' professional identity tensions. Teaching and Teacher Education, 80, 59-70. https:/ / doi.org/10.1016/j.tate.2019.01.001

Volkmann, M. J., \& Anderson, M. A. (1998). Creating professional identity: Dilemmas and metaphors of a first-year chemistry teacher. Science Education, 82(3), 293-310. https://doi.org/10.1002/(SICI) 1098-237X(199806)82:3<293::AID-SCE1>3.0.CO;2-7

Wang, M. T., \& Degol, J. (2013). Motivational pathways to STEM career choices: Using expectancy-value perspective to understand individual and gender 
differences in STEM fields. Developmental Review, 33(4), 304-340. https://doi.org/10.1016/j.dr.2013. 08.001

Wilkins, C. (2017). 'Elite' career-changers and their experience of initial teacher education. Journal of education for teaching, 43(2), 171-190. https:// doi.org/10.1080/02607476.2017.1286775

Williams, J. (2010). Constructing a new professional identity: Career change into teaching. Teaching and Teacher Education, 26(3), 639-647. https://doi.org/ $10.1016 /$ j.tate.2009.09.016

\section{http://www.ejmste.com}

